\title{
Artigo
}

\section{Ernesto Laclau e Chantal Mouffe e a análise do direito: mobilizando conceitos laclaunianos para a compreensão do fenômeno da judicialização da política e das relações sociais no Brasil}

Ernesto Laclau and Chantal Mouffe and the analysis of law: using Laclaunian concepts to understand the judicialization of politics and social relations in Brazil

\section{Igor Suzano Machado}

Professor Adjunto, Universidade Federal do Espírito Santo - UFES, Departamento de Ciências Sociais, Vitória, ES, Brasil igorsuzano@gmail.com

Resumo: Neste trabalho, saliento a utilidade do ferramental analítico e normativo da obra de Laclau e Mouffe como referencial teórico alternativo para a compreensão da judicialização da política e das relações sociais no Brasil. Tendo isso em vista, o presente trabalho irá se debruçar sobre cinco casos de interferência do Judiciário brasileiro na política e nas relações sociais, "traduzindo" suas tensões em categorias laclaunianas, como forma de melhor compreender as dinâmicas de ação dos grupos sociais envolvidos nos julgamentos. Primeiramente, tais casos serão analisados sob a égide de categorias analíticas laclaunianas como deslocamento, antagonismo, significantes vazios e hegemonia. Depois, refletir-se-á sobre a atuação do poder Judiciário de acordo com as lógicas do que Laclau e Mouffe chamam de "o social" e "o político". Por fim, a ideia de democracia radical dos mesmos autores será usada como referência para se pensar, normativamente, como um judiciário radicalmente democrático deveria ser constituído.

Palavras-chave: Laclau; Judicialização da política e das relações sociais; Antagonismo;

Hegemonia; Democracia radical. 


\begin{abstract}
This article emphasizes the usefulness of the analytical and normative tools of the work of Laclau and Mouffe as an alternative theoretical framework for understanding the judicialization of politics and social relations in Brazil. Considering that, this paper will focus on five cases of interference of Brazilian judiciary on politics and social relations, "translating" their tensions in laclaunianas categories, in order to better understand the dynamics of action of the social groups involved in the trials. First, such cases will be analyzed under the aegis of laclaunian analytical categories. Then, it will take place a reflection about the judicial practices in accordance with the logics of what Laclau and Mouffe call the "social" and the "political". Finally, the idea of radical democracy of the same authors will be used as a reference for thinking about how, in a normative point of view, a radically democratic judiciary could be established.
\end{abstract}

Keywords: Laclau; Judicialization of politics and social relations; Antagonism; Hegemony; Radical democracy.

\title{
Introdução: judicialização da política e hegemonia ${ }^{1}$
}

Desde o trabalho pioneiro de Tate e Valinder (1995), a expressão "judicialização da política" tornou-se parte do vocabulário de estudos sobre a relação entre a política e a justiça, inclusive no Brasil. Conforme destaca Ran Hirschl (2008, p. 119-123), a expressão tornou-se uma espécie de termo "guarda-chuva", para representar uma miríade de situações distintas. Ela se debruça, segundo o autor, especialmente sobre três processos inter-relacionados. Primeiramente, no nível mais abstrato, refere-se à disseminação do discurso, jargão, regras e processos jurídicos na esfera política e na formulação de políticas públicas - que muitos preferem se referir em termos de "juridificação". Em segundo lugar, num nível mais concreto, diz respeito à extensão da província de atuação dos juízes na formulação de políticas públicas e organização da burocracia e órgãos políticos, inclusive mediante atuação na defesa de direitos e garantias individuais, de forma a restringir a atuação dos poderes Executivo e Legislativo. Por fim, há ainda casos de judicialização da "megapolítica", em que juízes chegam a definir questões relativas à segurança nacional, planejamento econômico, processo eleitoral, etc.

A amplitude de temas relacionados ao guarda-chuva da judicialização gerou críticas, como a de que se trataria de um "[...] conceito pouco preciso, mas de rápida circulação pública [...]" (MACIEL; KOERNER, 2002, p. 131), ou mesmo, "[...] um nome atribuído a partir do início dos anos noventa ao protagonismo político de juízes, o

1 O presente trabalho dá continuidade a reflexão iniciada pelo autor em: Machado (2013). Como naquela oportunidade, gostaria de agradecer à Coordenação de Aperfeiçoamento de Pessoal de Nível Superior (Capes) (Proc.: BEX 2181/10-0) pela bolsa que me permitiu passar parte de meus estudos de doutorado em uma instituição estrangeira, e ao Departamento de Governo da Universidade de Essex que me aceitou como estudante visitante. Agradeço também à Fundação Carlos Chagas Filho de Amparo à Pesquisa do Estado do Rio de Janeiro (Faperj) pela bolsa de doutorado no Brasil. 
T\&P Ernesto Laclau e Chantal Mouffe e a análise do direito: mobilizando conceitos laclaunianos para a compreensão do fenômeno da judicialização da política e das relações sociais no Brasil

qual não apresentava qualquer novidade e não tinha implicações fundamentais para as democracias contemporâneas [...]", tratando-se de uma expressão "[...] teoricamente inválida, porque apresenta deslizes conceituais, ao simplificar as relações entre os tribunais e a política, revelando uma concepção estreita da jurisdição e do direito [...]" e apresentando "[...] uma abordagem parcial e enviesada sobre as transformações dos Estados contemporâneos [...]" e "[...] ambiguidades sobre seu campo de aplicação [...]" que a tornariam analiticamente inútil (KOERNER; INATOMI; BARATTO, 2011, p. 176-177).

Consequentemente, estudos mais específicos, mesmo que não necessariamente descartem completamente a expressão, têm tentado Ihe dar contornos mais críticos, ressaltando dimensões como a importância de processos de "juridificação", por exemplo, capitaneados pelo Ministério Público, que, contudo, não chegam à efetiva "judicialização" ao não abraçarem a litigância formal (ASENSI, 2008). Ou então, chamando atenção para, pelo contrário, os efeitos posteriores e reflexos da efetiva judicialização, por exemplo, mediante a reação dos poderes Executivo e Legislativo às decisões das cortes constitucionais (POGREBINSCHI, 2012). Mesmo Luiz Werneck Vianna e Marcelo Burgos, cujos trabalhos pioneiros ajudaram a popularizar a expressão "judicialização da política" no Brasil (VIANNA et al., 1999), colocaram em destaque, em discussão mais específica sobre ações civis públicas, a noção mais precisa "procedimentalização do direito" (VIANNA; BURGOS, 2003).

Tentando evitar ainda um certo viés "de cima para baixo" contido nos estudos sobre a judicialização, que dedicariam demasiada atenção à ação especificamente dos juízes e tribunais, há ainda autores, no Brasil (MACIEL, 2011; LOSEKANN, 2013) e fora do país, que apostam na noção de "mobilização do direito". Tal noção visaria prestar mais atenção às demandas da sociedade civil, sob um ponto de vista, digamos, "de baixo para cima", seja focando os litigantes individuais, seja em frutífero diálogo com a literatura sobre movimentos sociais em demandas coletivas (MCCANN, 2008, p. 523).

O presente estudo foca um tema clássico dos estudos sobre a judicialização da política: o controle de constitucionalidade das leis pelo Judiciário. Contudo, estará em foco a "[...] invocação pública de normas jurídicas para a regulação de conflitos e comportamentos [...]" indicando "[...] a ação de indivíduos, grupos ou organizações na promoção de reivindicações legais por meio das quais interesses, valores e demandas são traduzidos como questão de direitos [...]" (ZEMANS apud MACIEL, 2011), numa espécie de "sinédoque constitucional", representativa de uma categoria analítica 
sociológica de inspiração gramsciana que subjaz tanto estudos sobre a judicialização da política (HIRSCHL, 2008, p. 137), quanto sobre a mobilização de direitos (MCCANN, 2008, p. 530): a categoria "hegemonia", um termo referente ao conjunto de meios pelos quais a sociedade produz consenso e assegura a ordem, de forma que, nas palavras de Gramsci, uma dada classe social supera seus interesses meramente corporativos em prol de uma atitude dirigente, capaz de guiar intelectual e moralmente a sociedade como um todo.

Para fazer uso de um vocabulário contemporâneo que atualiza a noção gramsciana clássica, as práticas hegemônicas seriam operações de sinédoque, em que uma parte da sociedade a representaria como um todo. Utilizando-se de significantes de tendencial vacuidade, os grupos sociais articulariam determinados discursos e uma série de elementos discursivos em cadeias de significação capazes de dar à totalidade inteligibilidade. Por exemplo, o princípio da igualdade é representativo muito mais de uma totalidade ausente do que de uma objetividade pré-determinada. Trata-se de um significante vazio, pois só existe em suas manifestações concretas, mas não se confunde com elas, permitindo que vários grupos - ou seja, várias dessas manifestações concretas - disputem a posição de preencher o vazio desse significante e, consequentemente, a hegemonia construída em torno do mesmo (LACLAU; MOUFFE, 2006).

Assim, o presente trabalho propõe destacar, no estudo do Direito, a utilização da categoria hegemonia e de uma concepção "sinedótica" do movimento político, ou seja, uma concepção da política baseada no que, em termos retóricos, poder-se-ia considerar uma sinédoque: a substituição do todo pela parte. Isto é, a totalidade, o universal, direciona a ação política em geral, e nesse caso especificamente, a ação jurídica - mas não como um pressuposto, e sim como um horizonte. Toda universalidade é, dessa forma, uma particularidade que logra representar-se como universal por conseguir reunir, em torno de si, uma série de demandas que conseguem emergir por encontrar, nessa particularidade, o mais adequado significado para um significante que, por representar uma totalidade impossível em última instância, é tendencialmente vazio. Lida sob essa ótica, o Direito passa a ser uma construção hegemônica. A atividade jurisdicional assim, deixa de ser caracterizada catacreticamente como a atividade de uma mera"boca da lei", tal como queria Montesquieu, e, consequentemente, não pode ser lida sob um ponto de vista estritamente formalista. Pelo contrário, ela passa a ser entendida como parte de uma ação política estratégica que visa a obtenção da hegemonia. 
T\&P Ernesto Laclau e Chantal Mouffe e a análise do direito: mobilizando conceitos laclaunianos para a compreensão do fenômeno da judicialização da política e das relações sociais no Brasil

Dessa forma, o estudo a ser aqui desenvolvido busca analisar importantes decisões recentes da justiça brasileira e, partindo da teoria da hegemonia de Antonio Gramsci e desenvolvida contemporaneamente por Laclau e Mouffe (2006), interpretá-las como decisões políticas no seguinte sentido: em determinado contexto, certo grupo social se compreende como antagonizado por outro grupo e, estrategicamente, busca estabelecer, por mecanismos judiciais, nova hegemonia política, que efetive suas demandas enquanto interesses particulares que podem ser representados como interesse geral. A partir de cinco estudos de caso sobre pontos controversos da interferência do Poder Judiciário na política, a pesquisa busca operacionalizar tal referencial analítico e propor diretrizes teóricas para pesquisas empíricas e intuições normativas sobre a relação entre a política e a justiça no Brasil.

\section{Antagonismos, contingência e significantes de tendencial vacuidade}

Para Laclau e Mouffe (2006), a realidade contemporânea apresentaria uma situação de multiplicação de antagonismos sociais que podem se apresentar, da mesma forma que se apresentou na tradição marxista o antagonismo de classes, como um antagonismo especifico, mas cujo agente antagonizado seria capaz de agregar demandas e interesses advindos de posições subalternas de antagonismos outros e, assim, representar sua particularidade como universalidade. É essa operação de sinédoque, conforme salientado anteriormente, que Laclau e Mouffe (2006) caracterizam como hegemonia e que, nesse ponto, precisa ficar mais clara. Em primeiro lugar, é fundamental lançar luz sobre o que os autores consideram como antagonismo.

Segundo eles, a simples relação de oposição não seria capaz de definir um antagonismo, já que esta relação é condição necessária a qualquer identidade que será sempre negativa e relacional. Nesses termos, o escravo só seria escravo em oposição ao senhor e o senhor só seria senhor em oposição ao escravo, disso não decorrendo, necessariamente, qualquer antagonismo, mas apenas a fixação negativa dessas identidades.

O antagonismo ocorreria quando uma confluência de formações discursivas é capaz de criar entre elas ligações de sentido que fazem a relação de oposição do discurso original aparecer enquanto relação antagônica, ou seja, enquanto oposição na qual um 
dos polos impede a realização do outro. Isto é, o elemento que assume a identidade de escravo em face do senhor num discurso, assume, por exemplo, uma identidade de "igual perante Deus" em outro e encontra na oposição senhor-escravo do discurso original, um óbice à identidade de "cidadão" de um discurso terceiro, que, por sua vez, é ocupada por elementos que compartilham com ele a identidade de "igual perante Deus", mas não a identidade de escravo. Dessa forma, o antagonismo apareceria como uma clarificação ${ }^{2}$ da contingência da relação hierárquica contida na polarização entre duas identidades mutuamente implicadas. Tratando do caso da classe operária, afirma Laclau (2000, p. 33), inclusive, que:

Na medida em que se dá um antagonismo entre o operário e o capitalista, dito antagonismo não é inerente à relação de produção enquanto tal, mas se dá entre a relação de produção e algo que o agente é fora dela - por exemplo, uma baixa de salários nega a identidade do operário enquanto consumidor.

Os antagonismos sociais cumpririam assim, a dupla função de "bloquear" a plena constituição da identidade a que se opõem, mas, ao mesmo tempo condicionar a existência relacional dessa mesma identidade que não se constituiria à margem desse antagonismo, mas dentro dele mesmo. Essa relação entre bloqueio e afirmação simultânea de uma identidade é o que Laclau considera como gerador da contingência e o que introduziria o elemento de radical indecidibilidade na estrutura de toda objetividade, ao menos em última instância³ (LACLAU, 2000, p. 38). Tendo lugar num terreno de indecidibilidades estruturais, qualquer decisão implicaria sempre na repressão das decisões alternativas não tomadas, constituindo a "objetividade" resultante, necessariamente, como uma relação de poder, em seu sentido mais fundamental (LACLAU, 2000 p. 47).

Logo, dentro dessa indecidibilidade, o ato hegemônico não seria a realização de uma racionalidade que o precede, mas sim um ato de construção radical (LACLAU, 2000, p. 46). Assim, a contingência assumiria, em detrimento da necessidade, o caráter constitutivo do social, e toda identidade passaria a ser fonte potencial de um antagonismo.

2 "Nossa tese é que o antagonismo tem uma função revelatória, já que através dele se mostra o caráter em última instância contingente de toda objetividade" (LACLAU, 2000, p. 35).

3 Essa indecidibilidade em última instância, contudo, não implica que os agentes agirão sempre nessa última instância e serão assim eleitores absolutos entre todas hipóteses possíveis. Pelo contrário, quase nunca a ação social se desenvolverá nessa última instância. E disso decorre que, igualmente, dizer que uma decisão é tomada num nível de indecidibilidade em última instância, não permitindo um fundamento ontológico para uma decisão especifica, não implica afirmar que a irracionalidade desse momento de decisão retirará dela qualquer tipo de razoabilidade, já que a situação concreta fornecerá numerosos subsídios para o agente decidir num sentido e não em outro. 
T\&P Ernesto Laclau e Chantal Mouffe e a análise do direito: mobilizando conceitos laclaunianos para a compreensão do fenômeno da judicialização da política e das relações sociais no Brasil

E essa possibilidade sempre presente do antagonismo, essa inexorável contingência, conforme visto, seria o que Laclau e Mouffe (2006) consideram "o político", pertencente a um condicionante ontológico - em oposição a "a política", que articula o político no nível ôntico ${ }^{4}$.

Acontece que às vezes uma exclusão pode estar tão completamente sedimentada, o privilégio de um dos polos de uma relação dicotômica tão completamente estabelecido, que seu caráter contingente e sua dimensão originária de relação de poder não resultam imediatamente visíveis. Essas formas sedimentadas de "objetividade" constituiriam o campo denominado pelos autores como o campo do "social". É por isso que em Laclau e Mouffe haveria uma primazia da política - enquanto articulação do político que não se restringe à esfera estatal - sobre o social, pois o primeiro seria responsável pela definição e os limites do segundo (LACLAU, 2000, p. 50-51)5.

Contudo, dos antagonismos surgirão, necessariamente, demandas particulares. A articulação hegemônica consistiria exatamente em transformar essas demandas particulares em demandas universais. Obviamente, essa transformação seria operada de forma incompleta e precária, já que se encontraria maculada por sua natureza, em última instância, particular. Mas essa seria a consequência de abandonar qualquer essencialismo da sociedade: não seria mais possível falar de um reencontro da sociedade consigo mesma enquanto essência, mas apenas da hegemonia de um discurso como forma possível de suturar sua contingência constitutiva. Seria essa sutura precária e mais, ou menos, efêmera, dependendo do caso concreto, que representaria, no pensamento de Laclau e Mouffe, o conceito gramsciano de bloco-histórico, isto é, de unidade e estabilidade social temporária em torno de certas ideias e valores (LACLAU e MOUFFE, 2006, p. 180).

Para a compreensão da articulação hegemônica enquanto forma de universalização de demandas particulares é ainda importante ter em mente as noções de significantes

4 Aqui eu uso a distinção heideggeriana assimilada por Laclau e Mouffe (2006) onde "ôntico" faz referência a manifestações concretas de certos seres, enquanto "ontológico"faz referência a uma origem mais abstrata e fundacional desses seres. Para tornar a distinção mais clara, por exemplo, pode-se dizer que as reflexões das teorias política e social lidam com a dimensão ontológica da política e da sociedade, enquanto as pesquisas de ciência política e sociologia lidam com manifestações ônticas desses fenômenos. É nesse sentido que a terminologia será usada neste artigo.

5 Uma clarificação acerca da noção de primazia da política sobre o social em Laclau, no entanto, faz-se necessária para que essa hierarquia não seja vista como uma redução da construção da sociedade a um decisionismo voluntarista. Isso só seria possível se a política fosse concebida como radicalmente separada do social. Porém ela não é nem completamente interna, nem completamente externa ao social, mas sim possui o status de um hímen, no sentido derridiano do termo, como algo que permanece entre dois extremos sem ser consumido por nenhum deles - nesse caso, estando entre a indecidibilidade que permite a mudança e a sedimentação que a impede. Sendo assim, a indecidibilidade do social é condição de possibilidade da política. Contudo, haverá sempre um conjunto de práticas sedimentadas que condicionam a formulação, a realização e a transformação de estratégias políticas responsáveis formatar e reformatar as relações sociais (TORFING, 1999, p. 70-71). 
flutuantes e de significantes vazios 6 . Ao equivalente geral que unifica uma cadeia inalterada de equivalências, Laclau dá o nome de significante vazio; àquele cuja vacuidade é resultado da não fixação introduzida por uma pluralidade de discursos que se interrompem uns aos outros, ele designa com o termo significante flutuante (LACLAU, 2004, p. 305).

Assim, os significantes vazios seriam significantes que, mesmo sem se relacionarem a um significado específico, continuam fazendo parte de um sistema simbólico pela experimentação de sua negação radical, a experimentação de sua falta, de sua ausência. A prática da hegemonia possuiria relação direta com a disputa por preencher com significados específicos os significantes vazios nos momentos de crise em que esses significados específicos tendem a se afastar de seu significante, provocando um deslocamento na estrutura relacional em que estão inseridos.

Os significantes vazios costumam aparecer em termos de forte apelo universalista, como "ordem" ou os valores ético-políticos destacados por Mouffe de igualdade e liberdade, assumindo posição central na transformação de antagonismos particulares em demandas universalizadas. Por exemplo, seguindo Laclau (1996, p. 44)

Consideremos a situação extrema de uma radical desorganização do tecido social. Nessas condições - que não estão muito distantes do estado de natureza hobbesiano - as pessoas necessitam de uma ordem, e o real conteúdo disso se torna uma consideração secundária. "Ordem" como tal não possui conteúdo, porque ela só existe nas várias formas nas quais ela é atualmente realizada, mas numa situação de radical desordem a "ordem" se torna presente como o que está ausente; ela se torna um significante vazio, o significante de uma ausência. Nesses termos, várias forças políticas podem competir em seus esforços para apresentar seus objetivos particulares como aqueles que realizariam o preenchimento dessa ausência. Hegemonizar algo é exatamente realizar essa função de preenchimento. (Falamos de "ordem", mas obviamente "unidade", "liberação", "revolução", etc. pertencem à mesma ordem de coisas. Qualquer termo que, num determinado contexto político se torna o significante da falta desempenha o mesmo papel. A política é possível porque a impossibilidade constitutiva da sociedade só pode se representar através da produção de significantes vazios).

A presença do significante vazio pode ser representada também pelo seguinte esquema, representado pela Figura 1:

6 Conforme ficará mais claro adiante, um significante não se torna vazio por operações nem de abstração, nem de formalização. Sendo assim, nesse caso, vazio não quer dizer meramente formal e não possui relação direta e necessária com abstrato. 
Figura 1. Significante vazio. Fonte: Laclau (2007, p. 164).

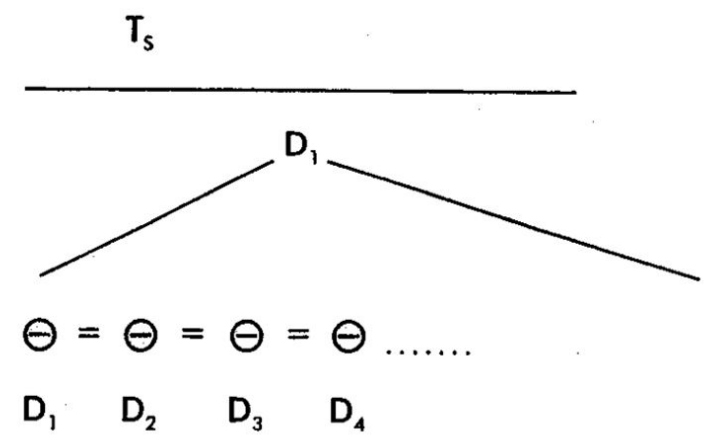

Nesse esquema, a letra " $T$ " representa um regime opressor; a linha horizontal representa a fronteira que separa o regime opressor do resto da sociedade; os círculos “ $\mathrm{D}_{1}$,.... $\mathrm{D}_{4}$ "representam as demandas particulares, que estão divididas em um semicírculo inferior que representa a particularidade da demanda e um semicírculo superior que representa seu significado anti-sistema, o qual permite suas relações de equivalência. Por último, a“" ${ }_{1}$," localizada acima dos círculos de equivalência, representa o equivalente geral, que forma parte da cadeia de equivalência, mas que, contudo, está sobreposto a ela (LACLAU, 2004, p. 302-3). Para realizar essa tarefa, $D_{1}$ precisaria de se configurar como o que Laclau considera um significante vazio.

Já os significantes flutuantes seriam significantes que, pela sobredeterminação inevitável de seu sentido, poderiam ser deslocados de um discurso e ter seu significado reapropriado em discurso outro concorrente, adquirindo nova identidade e transformando, da mesma forma, a totalidade do novo discurso. Seriam fundamentais às práticas hegemônicas pela capacidade de instituir ligações entre as cadeias discursivas pelas quais tais significantes "flutuam". Mais uma vez, tomando um exemplo do próprio Laclau (1996, p. 94-5),

Suponhamos um discurso político asseverando que"o Partido Trabalhista é mais capaz que o Partido Conservador para assegurar a unidade do povo britânico". Numa proposição como essa, que é absolutamente comum na disputa política, nós temos uma entidade -"a unidade do povo britânico" - que é qualitativamente diferente das outras duas - Partido Trabalhista e Partido Conservador. Primeiramente, temos que essa unidade é algo a ser conquistado, portanto, ao contrário das outras duas entidades, ela não é algo verdadeiramente existente, mas o nome de uma plenitude ausente. Contudo, em segundo lugar, o tipo de unidade política que Trabalhistas e Conservadores realizariam seria substancialmente 
diferente, portanto se o termo unidade significasse uma entidade concreta no mesmo nível das duas forças políticas, a proposição seria quase tautológica - seria o equivalente a dizer que"o Partido Trabalhista é mais capaz que o Partido Conservador para assegurar um tipo trabalhista de unidade do povo britânico". Obviamente não é isso que a proposição original pretende dizer. Assim, por um lado, as várias forças políticas dotam de conteúdo concreto a unidade, sem o qual ela não pode existir, mas, por outro, essa unidade não é completamente exaurida por qualquer dessas alternativas de conteúdo concreto. "Unidade" é um significante flutuante porque seus significados são fixados apenas pelos conteúdos concretos providos pelas forças antagônicas; porém, ao mesmo tempo, essa flutuação não é uma flutuação puramente contingente e circunstancial, porque sem ela a disputa política seria impossível e a vida política seria um diálogo entre surdos, no qual teríamos apenas proposições incomensuráveis.

Com base no esquema anterior, os significantes flutuantes também podem ser representados graficamente, nos moldes da Figura 2:

No novo esquema, $\mathrm{D}$, passa a estar submetido à pressão de duas cadeias de equivalências antagônicas, representadas pelas linhas pontilhadas: a horizontal corresponde à oposição ao regime opressor T do primeiro diagrama. A diagonal, no entanto, estabelece um laço de equivalência entre $D_{1}$ e outras demandas, não necessariamente contrárias ao regime opressor, apresentando, portanto, formas antagônicas de constituir o significado de $\mathrm{D}_{1}$. O modo como tal significado será definido dependerá de uma luta hegemônica. Portanto, a dimensão flutuante se tornaria mais visível nos períodos de crise, quando o sistema requer reformas mais radicais. Por isso mesmo, essa dimensão teria como

Figura 2. Significante flutuante. Fonte: Laclau (2007, p. 166). 
padrão necessário a indefinição das relações entre os semicírculos de representação dos elos das cadeias: é sempre o semicírculo superior que se torna autônomo em qualquer flutuação, já que seria em suas virtudes de equivalência que repousaria a representação da plenitude (ausente) da sociedade (LACLAU, 2007, p. 166).

Com isso tornar-se-ia claro que as categorias de significantes vazios e flutuantes são estruturalmente diferentes: a primeira teria a ver com a construção de uma identidade por meio de uma fronteira estável que se pressupõe; a segunda buscaria apreender conceitualmente a lógica dos deslocamentos dessa fronteira. Na prática, no entanto, a distância entre ambas não seria tão grande. Tratar-se-ia de dois tipos de operação hegemônica e frequentemente as duas referências se sobreporiam. Uma situação em que apenas a categoria de significante vazio fosse relevante, excluindo o momento de flutuação, seria uma situação irreal em que se faria presente uma fronteira completamente imóvel. Por outro lado, um universo psicótico em que as flutuações não contassem com nenhuma fixação parcial, seria também igualmente impensável. Ou seja: tanto significantes flutuantes quanto significantes vazios devem ser tomados como dimensões parciais e complementares de qualquer processo de construção hegemônica (LACLAU, 2007, p. 168). Em geral, ambas as situações são referidas como de "significantes de tendencial vacuidade".

A hegemonia apareceria dessa forma como um jogo de equivalências e diferenças; uma prática política que se tornaria especialmente visível numa sociedade marcada pela transparência dos antagonismos e pela contingência das identidades, na qual seria possível reorganizar os elementos/momentos de seus discursos constitutivos de forma a aglutinar ou excluir interesses e reposicionar barreiras delimitadoras da identidade de seus agentes. Com a forte atenção que dedicam à dimensão do simbólico e à retórica, é comum, inclusive, a referência de Laclau e Mouffe, em seus escritos, a figuras de linguagem como a metáfora, a metonímia e a sinédoque, quando falam sobre relações hegemônicas.

Isso porque a sobredeterminação de sentido metafórica, ao substituir um termo por outro que guarda com o termo original uma relação de similitude ou de analogia, permitiria a transgressão dos limites entre discursos pela lógica da equivalência. Da mesma forma, se a metonímia permite a substituição de um termo por outro que guarda com o original uma relação de contiguidade, como tomando a causa pelo efeito, o recipiente 
pelo conteúdo e vice-versa, também se estaria diante de uma subversão de sentido capaz de expandir cadeias de significação e transgredir limites postos de identidades sociais. Por fim, com a sinédoque, tipo especial de metonímia na qual a relação entre os termos contíguos implica um dos termos estar contido no outro, substituindo o gênero pela espécie, a parte pelo todo, o singular pelo plural e vice-versa, estar-se-ia diante do movimento privilegiado de uma relação hegemônica, em que parte específica do social, determinado grupo que articula certas demandas ${ }^{7}$ assumiria a representação da sociedade como um todo ${ }^{8}$, realizando seu fechamento parcial e precário em torno de um determinado bloco-histórico.

Com isso, é possível identificar quatro dimensões da hegemonia, que seriam:

1. a desigualdade de poder Ihe é constitutiva e, dessa forma, um grupo, ou constelação de grupos, particular estará em melhores condições do que outros para representar o todo, articulando interesses a seu redor e carregando em si a possibilidade de vitória frente ao adversário (LACLAU, 2007, p. 59). Contudo,

2. há hegemonia somente se se supera a dicotomia universalidade/particularidade; a universalidade só existe se se encarna numa particularidade - e a subverte mas nenhuma particularidade pode, de maneira inversa, tornar-se política se não se converteu também em locus de efeitos universalizantes (LACLAU, 2007, p. 61). Mas para que consiga isso

3. a hegemonia requer a produção de significantes de vacuidade tendencial que, ao mesmo tempo que mantêm a incomensurabilidade entre universal e particulares, permite que os últimos assumam a representação do primeiro (LACLAU, 2007, p. 62). Portanto,

4. o terreno no qual se estende a hegemonia é o da generalização das relações de representação como condição da ordem social (LACLAU, 2007, p. 63).

De maneira bastante sumária, essas são as principais categorias desenvolvidas por Laclau e Mouffe para a compreensão da sociedade e as atividades políticas que lhe dão forma, sob uma ótica antiessencialista e pós-estruturalista. O objetivo deste trabalho é

7 Como a identidade de um grupo já é uma prática articulatória, Laclau concebe como mais básica unidade de análise as demandas que esse grupo articulará de forma a constituir sua identidade (LACLAU, 2007, p. 9).

8 Este é o ponto em que a transferência metonímica tem lugar: tal como o ouro tem a dupla função de ser seu próprio valor de uso e de encarnar a forma geral do valor, assim a particularidade concreta de uma instituição ou força social assume a função de representação da universalidade como tal (LACLAU, 1996, p. 92). 
T\&P Ernesto Laclau e Chantal Mouffe e a análise do direito: mobilizando conceitos laclaunianos para a compreensão do fenômeno da judicialização da política e das relações sociais no Brasil

averiguar se e de que forma tais categorias são capazes de auxiliar a compreensão do Direito enquanto fenômeno social, especialmente no que tange à chamada judicialização da política.

\section{Os casos estudados}

O fio condutor capaz de guiar a seleção dos casos empíricos pesquisados será tomar como base para tanto, a princípio, os temas de debate dos três primeiros capítulos da obra Juízes na democracia contemporânea [Judges in contemporary democracy] (2004), organizada por Badinter e Breyer (2004). Assim sendo, serão selecionadas sentenças que de alguma forma versem sobre três temas fundamentais à atividade contemporânea dos juízes em regimes democráticos. São eles: o ativismo do Judiciário, substituindo os demais poderes na tarefa legislativa; o funcionamento do Judiciário como um pontificado laico, agindo como espécie de substituto moral das religiões; e o exercício pelo Judiciário da supervisão do processo eleitoral, em detrimento de partidos e eleitores. Tendo isso em vista, serão analisados os seguintes casos:

- Mandados de injunção (m.i.) no 670, 708 e 712, em que o Supremo Tribunal Federal (STF) regulou o direito de greve do servidor público, caso de "ativismo" em que o Poder Judiciário cumpriu funções, em tese, do Legislativo e Executivo;

- Ação Direta de Inconstitucionalidade (ADI) 3510, que decidiu sobre a pesquisa com células-tronco embrionárias, levando ao Judiciário questões de forte conotação moral, aproximando-o do que foi chamado no livro de um pontificado laico;

- ADIs 3999 e 4086, nas quais o STF confirmou a fidelidade partidária exigida em resolução do Tribunal Superior Eleitoral (TSE), interferindo diretamente na competição eleitoral.

O primeiro caso, portanto, refere-se ao julgamento conjunto dos mandados de injunção 670, 708 e 712. Para melhor contextualizar tal caso, primeiro faz-se necessário explicar em que se constitui o mandado de injunção. Tal instrumento jurídico foi previsto pela Constituição de 1988 como um remédio institucional contra a omissão legislativa tida como inconstitucional, isto é, quando o legislativo deixar de legislar assunto que a Constituição Ihe exigiu regulamentação. O mecanismo foi previsto como forma de garantir a efetividade constitucional, para que a vigência dos preceitos ditados pelos 
legisladores da constituinte não tivesse seus efeitos obstruídos pela falta de ação do legislador ordinário.

Por exemplo, a Constituição prevê um direito, mas condiciona seu exercício à regulamentação prevista em lei. Nesse caso, se o Congresso Nacional não promulga tal lei, pode o cidadão que se sinta prejudicado impetrar mandado de injunção para que a lei seja promulgada e seu direito garantido. Um caso clássico, que é justamente o tema dos mandados de injunção 670, 708 e 712 é o direito de greve do servidor público, garantido explicitamente no texto constitucional, mas igualmente condicionado a regulação a ser descrita em lei - inicialmente, lei complementar, mas, depois da emenda constitucional 19/98, lei ordinária9?. E, tal lei, até então, não havia sido promulgada pelo Congresso.

A complicação que se depreende daí é clara: qual deve ser o efeito do julgamento de um mandado de injunção? Obrigar o Legislativo a legislar? Permitir ao Judiciário exercer função legislativa perante a inércia do parlamento? Apenas reconhecer a mora legislativa? Criar lei para apenas aquele que ingressou com o mandado de injunção e deixar demais possíveis afetados sem regulamentação do seu direito? Essas foram algumas questões que atravessaram não só os mandados de injunção em análise, mas também outros mandados de injunção anteriores, que versavam sobre o mesmo tema. Interessante notar que, nesses mandados anteriores, o resultado foi o entendimento de que o mandado de injunção serviria apenas ao reconhecimento da inércia legislativa, quando muito, estipulando um prazo para que tal lacuna legal fosse sanada, mas sem conter meios de tornar tal prazo coercitivo, deixando-o apenas como uma recomendação ao legislador. Contudo, nos mandados aqui analisados o entendimento predominante foi outro: diante da inércia do Legislativo, o Judiciário deveria formular a regra ainda não criada.

Se esse primeiro caso é um exemplo de judicialização da política motivado por um "caso quente" evitado pelo Legislativo pelo custo em votos que sua regulação poderia ter, o segundo caso a ser estudado representa situação bem diferente. Trata-se do julgamento da ADI 3510, que questionava a constitucionalidade do art. $5^{\circ}$ da chamada lei de biossegurança, que permite o uso de células-tronco embrionárias para fins de pesquisa científica. Nesse caso, é atacada lei já aprovada dentro do processo legislativo

9 O objetivo dessa mudança foi, justamente, devido à demora na aprovação de tal lei, simplificar o quórum necessário para a sua aprovação, já que a lei ordinária requer apenas maioria simples e não qualificada. 
T\&P Ernesto Laclau e Chantal Mouffe e a análise do direito: mobilizando conceitos laclaunianos para a compreensão do fenômeno da judicialização da política e das relações sociais no Brasil

tradicional e o Judiciário passa a ser uma nova instância de disputa política para aqueles que foram voto vencido no procedimento legislativo ordinário.

Isso faz com que a força a desestabilizar o discurso constitucional seja diferente e a oposição de entendimentos sobre o que é a Constituição se processe de forma também distinta, internamente à assunção de sua função de carta de direitos a serem efetivados. Com isso, não se discute diretamente a oposição entre a efetivação de direitos e a divisão de poderes, mas os diferentes significados possíveis desses direitos a serem efetivados e as consequências daí advindas. Mesmo assim, os ministros permanecem o tempo todo tentando delimitar suas próprias funções por meio de diferenciações em face de funções outras. Contudo, em vez de diferenciarem as funções legislativas e judiciárias, buscam diferenciar os argumentos jurídicos de argumentos religiosos, morais e científicos. Mais uma vez está em jogo a distinção da função judiciária e a disputa por preencher, com significado específico, significantes que se tornaram vazios pelo excesso de representações que abarcam.

Se o primeiro caso versa sobre um "caso quente", judicializado por ser evitado pelo Legislativo por seu alto custo em termos de votos, e o segundo caso diz respeito a um caso judicializado pelo fato de o Judiciário poder se apresentar como nova instância de disputa política sobre tema já decidido pelo Legislativo, o terceiro caso aparece como uma intersecção desses dois modelos. Trata-se de um assunto quente para os partidos políticos: a regulação da competição eleitoral. Mas que também foi judicializado para buscar nova instância de decisão, buscando reverter uma judicialização anterior. Ele diz respeito a regulações do TSE que depois foram questionadas junto ao STF. Isto é, decisões de um órgão do Judiciário questionadas junto a outro órgão do Judiciário.

Esse caso paradigmático é o julgamento das ADls 3999 e 4086. Essas são as duas ADls que questionaram as resoluções 22.610/07 e 22.733/2008 do TSE nas quais foi reconhecido que os cargos eletivos pertenciam aos partidos e não aos candidatos e que, no caso de infidelidade dos últimos, o cargo vagaria em benefício do partido pelo qual o candidato havia sido eleito. O Partido Social Cristão e o Procurador-geral da República argumentaram então, por meio das ADls, que o TSE teria invadido competência privativa do legislador para a regulação da competição eleitoral ao definir nova forma de perda de mandato: a infidelidade partidária sem justa causa. O STF, no entanto, reconheceu por maioria de votos a constitucionalidade das resoluções e confirmou como válida a desfiliação partidária por infidelidade. 
Cumpre destacar, contudo, que, para além desses casos, existe a necessidade de trazer à análise também casos em que decisões divergentes de mais de uma instância mostrem possibilidades distintas de interferência do Judiciário na política e vida social. Trazer à discussão casos desse tipo contribuiria para realçar a pluralidade de reconstruções discursivas permitidas pelo ordenamento jurídico brasileiro, realçando, por sua vez, como elas podem entrar em conflito e como a estrutura hierárquica do Poder Judiciário atua na consolidação de determinado entendimento como dominante.

Para a seleção desses casos foi utilizado como critério, novamente, o tema tratado nos processos. No entanto, sem a orientação de obra específica, como nas outras decisões, foram privilegiados dois temas de abrangência e importância nacionais e históricas. De um lado, a discussão das relações entre capital e trabalho e a liberdade de empregadores frente a empregados, fundamental a qualquer realidade capitalista. E, do outro, a discussão da questão racial, tema fulcral na formação social brasileira. Tendo em vista tais temas, serão analisadas as seguintes decisões:

- O processo n. 00309-2009-000-15-00-4 do Tribunal Regional do Trabalho (TRT) da 15 a região, que concedeu liminar reintegrando mais de 4 mil trabalhadores demitidos pela EMBRAER, assim como do processo n. ES-207660/2009-000-00-00.7 do Tribunal Superior do Trabalho (TST), que, por seu turno, em decisão monocrática, cassou a liminar, confirmando a validade das demissões, acompanhados, por fim, da decisão colegiada do TST que, mesmo confimando a validade das demissões, adotou entendimento próximo ao do TRT para casos a serem julgados no futuro.

- O mandado de segurança no. 2007.72.00.014734-6, julgado por juiz federal de Santa Catarina, que concedeu liminar permitindo a matricula na Universidade Federal de Santa Catarina (UFSC) de aluna inicialmente não classificada no exame vestibular devido ao sistema de cotas, assim como do Agravo de instrumento no. 2008.04.00.000858-7, do Tribunal Regional Federal (TRF) da 4ª região, responsável, justamente, por derrubar tal liminar.

Logo, se o STF, enquanto vértice do sistema judicial brasileiro e derradeiro intérprete das normas constitucionais ocupa posição de destaque na consolidação das exigências da Constituição de 1988 e, assim, é instância de profunda judicialização da política e das relações sociais ocasionadas justamente pelos anseios do texto constitucional, nem por isso esse fenômeno se restringe às decisões da suprema corte brasileira. Como zelar pelo 
T\&P Ernesto Laclau e Chantal Mouffe e a análise do direito: mobilizando conceitos laclaunianos para a compreensão do fenômeno da judicialização da política e das relações sociais no Brasil

cumprimento da Constituição é obrigação de todos os órgãos da justiça que devem, inclusive, exercer um controle difuso de constitucionalidade das leis, a judicialização ocasionada pela carta constitucional de 88 também se manifesta em decisões de juízes de primeira instância e de demais tribunais locais ou regionais do país. Exemplo disso são as decisões a serem analisadas no $4^{\circ}$ caso estudado. Trata-se de um conjunto de decisões que, em duas diferentes instâncias, enfrentou judicialmente uma divergência entre patrões e empregados da indústria aeronáutica, tentando enxergar qual seria a melhor resolução da controvérsia tendo como parâmetro os valores prescritos na Constituição.

A primeira dessas decisões é a decisão do desembargador do TRT da 15a região, Luis Carlos Cândido Martins Sotero da Silva, no processo 00309-2009-000-15-00-4, em que o Sindicato dos metalúrgicos de São José dos Campos e região, o Sindicato dos metalúrgicos de Botucatu e a Federação de metalúrgicos de São Paulo questionaram judicialmente a demissão coletiva empreendida pela EMBRAER (Empresa Brasileira de Aeronáutica) sob a justificativa de diminuir custos e, assim, enfrentar a crise econômica mundial de 2008/2009. Como se trata de empresa fortemente dependente do mercado internacional, a EMBRAER se viu às voltas com uma situação de urgência, em que se faziam necessárias medidas drásticas. Tendo isso em vista, a empresa optou pela demissão coletiva - de 4.200 trabalhadores - como forma de diminuir custos e enfrentar a crise. Contra tal ato de ingerência administrativa dos empregadores, sindicatos representativos dos trabalhadores demitidos recorreram ao Poder Judiciário solicitando liminar capaz de anular tais demissões apelando a princípios constitucionais que, na visão dos sindicatos, não davam guarida à conduta dos empregadores. Argumentavam, como destaca em sua decisão o próprio desembargador, que "[...] o poder diretivo do empregador, consubstanciado na possibilidade de rescindir unilateralmente os contratos de trabalho dos empregados, não é absoluto, encontrando limites nos direitos fundamentais da dignidade da pessoa humana," constitucionalmente garantidos e capazes de permitir a judicialização da demanda.

Como qualquer nação capitalista, o Brasil é atravessado por conflitos entre o capital e o trabalho. Com isso, a hierarquia entre empregadores e empregados se reflete em conflitos levados ao Judiciário, como o analisado anteriormente. No entanto, o Brasil também tem marcas constitutivas próprias, que estabelecem outros tipos de hierarquias entre seus cidadãos. Dentre essas "marcas de nascença" da nação podem ser destacados os institutos do latifúndio e da escravidão. Por conta dessa última e dos desdobramentos de seu longo período de vigência e da forma de seu encerramento, uma marca física, a cor da pele, 
passou a ser indicativa de uma posição desfavorecida na sociedade brasileira. Assim, políticas públicas visando a inserção social do negro passaram a ser pensadas e articuladas pelo poder público, dentre as quais se destacam as políticas de cotas de acesso à universidade.

No entanto, sendo as vagas universitárias bens escassos e valorizados, sua reserva a parcela específica da população gera tensões que respondem a interpretações concorrentes a respeito de um padrão de justiça de larga aceitação: a igual consideração e respeito por todos. Afinal, para que todos sejam considerados como iguais, todos devem possuir a mesma chance de acesso à universidade ou se deve dar preferência, nesse acesso, a parcela da população historicamente excluída socialmente? Como era de se esperar, tal conflito também tende a buscar solução no Poder Judiciário, guardião dos parâmetros constitucionais de justiça, dentre os quais tem destaque o princípio da igualdade.

Esse é o pano de fundo das decisões escolhidas para o último caso estudado. Trata-se das decisões, primeiramente, do mandado de segurança 2007.72.00.014734-6/SC, tanto em sede de liminar, quanto de sentença, e depois do agravo de instrumento ${ }^{10}$ n' 2008.04.00.000858-7/SC que questiona a liminar concedida. A autora do mandado alega que o sistema de vestibular da UFSC para o ingresso dos estudantes em suas turmas, ao criar "um sistema de cotas raciais, com reserva de vagas dos cursos para negros e índios" estaria em "[...] flagrante afronta ao direito de igualdade entre os cidadãos estabelecido na Declaração dos Direitos do Homem e do Cidadão, na Declaração Universal dos Direitos Humanos e na Constituição Federal de 1988". Como se aproximava a data das provas, a autora requereu também que Ihe fosse concedida medida liminar que garantisse seu acesso à totalidade das vagas oferecidas pela universidade, mesmo antes do julgamento final do mandado.

Conforme dito anteriormente, o conjunto de decisões judiciais citado acima será analisado como conjunto de decisões políticas, isto é, ações estratégicas que buscam amortizar um antagonismo social e produzir a consolidação de uma hegemonia na qual, de forma precária e contingente, um determinado grupo consegue representar seus interesses particulares como interesse geral. Ao analisar as decisões judiciais dessa maneira, o estudo oferece uma leitura alternativa da recente “judicialização da política” no Brasil. Em primeiro lugar, não considera a decisão judicial uma decisão eminentemente técnica, que encontra na sua politização um desvio. Pelo contrário, usando a distinção estabelecida por Laclau

10 Recurso específico para decisões interlocutórias, isto é, que não julgam o mérito. 
e Mouffe entre o "social" e o "político", o trabalho busca explicar porque haveria decisões jurídicas aparentemente técnicas que seriam, em última instância, políticas. Em segundo lugar, não considera a decisão judicial como decisão moral, isto é, decisão que representa a consagração de uma justiça universal. Nisso, afasta-se de perspectivas normativas tanto de juristas como Ronald Dworkin, quanto de sociólogos como Jürgen Habermas. Por fim, mesmo que negue o universalismo liberal como dimensão a ser buscada pela integridade do Direito, o trabalho também não aceita uma hiperfragmentação de tipo pós-moderna. Ou seja, aceitar a dimensão política da decisão jurídica, seguindo o referencial teórico de Laclau e Mouffe (2006), não implica afirmar nem que ela seja moralmente universal, nem completamente particularista, mas sim encará-la como uma particularidade que consegue representar o universal.

\section{Deslocamento, antagonismo e hegemonia nos tribunais brasileiros}

Com base nesses cinco estudos de caso, que conclusões podem ser feitas a respeito das lógicas que informam tais decisões judiciais? O que a análise das decisões demonstra, é que, entre um entendimento do Direito como vinculado à unidade moral, e um entendimento do Direito vinculado à diversidade político-partidária, os juízes brasileiros se comportam atendendo ao chamado do primeiro entendimento, tão bem representado, por exemplo, pela teoria de Dworkin (2003). Porém, a unidade moral que esses juízes tentam representar em seus julgamentos não reflete a justiça liberal preconizada por Dworkin (2011). Não se trata de uma justiça meramente formal, nem ligada à concretização dos procedimentos habermasianos: ela visa, como em Dworkin, a efetivação de princípios substantivos. Mas, diferentemente de em Dworkin, esses princípios não se esgotam nos cânones liberais. Por exemplo, o, em tese, individualista princípio da proteção da dignidade humana, ganha contornos solidários que fazem alguns ministros do STF reconhecerem dignidade no embrião humano, mas relativizarem essa dignidade em prol da dignidade de quem aguarda a cura de doenças que podem advir das pesquisas com células-tronco embrionárias .

Isso faz com que a própria divisão proposta por Dworkin entre argumentos de princípio e argumentos de política (DWORKIN, 2005) se dilua e a linguagem dos direitos, em certo sentido, possa servir à consecução de melhorias coletivas, como também transparece 
nas interpretações acerca da constitucionalidade do sistema de cotas universitárias. Esse comportamento dos juízes mostraria, portanto, que, de fato, a dimensão de unidade moral para a regulação da atividade política não seria mais do que uma máscara para uma escolha política possível dentre várias? As críticas dos autores que chamam mais atenção para a dimensão social do dissenso, como pragmatistas, multiculturalistas, feministas e marxistas, seria assim, mais correta do que o entendimento proposto por Dworkin? Haveria outra maneira de compreender esse "desvio" dentro da cartilha dworkiniana?

O problema é que, de um lado, o aspecto mais profundamente normativo das teorias jurídicas, em que se destaca a ideia de Dworkin de que existe uma única resposta correta para os casos jurídicos, corre o risco de lançar as decisões judiciais, quando tomadas na esteira da efetivação de direitos sociais e coletivos, numa vala comum de decisões incorretas ${ }^{11}$. E, do outro lado, uma visão do direito que não reconhece a possibilidade de fundamentação jurídica numa dimensão de consenso em torno de princípios leva a uma leitura da atuação dos juízes - que, de acordo com o que se observa nas decisões analisadas, esforçam-se por fundamentar suas decisões distanciando-se do subjetivismo, relativismo e pragmatismo - capaz de conduzir a um "denuncismo" arrogante, no qual cabe ao analista destacar que os juízes fazem o jogo de um grupo dominante, mesmo que não tenham consciência disso, como se apenas o analista externo fosse capaz de compreender tal fenômeno, enquanto os operadores do direito reproduziriam ilusões de integridade, inclusive, para si mesmos, ou então, seriam apenas mal intencionados.

Contra esses dois extremos, o presente trabalho propõe integrar ao estudo do Direito a categoria hegemonia e uma concepção sinedótica do movimento político. Isto é, a totalidade, o universal, direciona a ação política em geral, e nesse caso especificamente, a ação jurídica, mas não como um pressuposto, e sim como um horizonte. Toda universalidade é, dessa forma, uma particularidade que logra representar-se como universal por conseguir reunir em torno de si uma série de demandas que conseguem emergir por encontrar nessa particularidade o mais adequado significado para um significante que, por representar uma totalidade impossível em última instância, é tendencialmente vazio. A coincidência, sempre precária e reversível, entre esse significado particular e esse significante da universalidade é o que Laclau considera como hegemonia. E o que a análise das decisões estudadas parece demonstrar é que uma leitura da jurisdição

11 O que, do ponto de vista estritamente normativo, por suposto, continua um procedimento válido. 
T\&P Ernesto Laclau e Chantal Mouffe e a análise do direito: mobilizando conceitos laclaunianos para a compreensão do fenômeno da judicialização da política e das relações sociais no Brasil

brasileira embasada nessa chave de compreensão ajudaria a compreender melhor a sistemática da atual judicialização da política que tem como corolário e como outro lado da mesma moeda uma politização da justiça.

O primeiro movimento presente numa configuração hegemônica, tal como caracterizada por Laclau, é o chamado "deslocamento", que pode ser entendido como uma "emergência do real", no sentido lacaniano do termo real. Isto é, a sociedade é uma totalidade discursiva, mas que conta com uma realidade que a ultrapassa, que é a realidade que não faz parte da sociedade por não ter sido assimilada discursivamente, escapando, portanto à compreensão. Essa realidade é o que Lacan chama de"real" que não se confunde com o "simbólico" que permite a intermediação inteligível entre os seres humanos e as coisas em si. Isso não impede que o que escapa à simbolização, mesmo que não seja compreendido, cause efeitos. A essa "emergência do real", isto é, a emergência de eventos que não conseguem ser assimilados dentro de formações discursivas prévias, é o que Laclau considera um "deslocamento". É esse deslocamento que instaura a instabilidade dentro dos discursos relativamente estáveis sedimentados na sociedade e abre espaço para a ação política, propriamente transformadora. É ele que não somente requer a ação do sujeito, mas sim que permite essa ação, já que, superado esse deslocamento pela assimilação discursiva dos elementos deflagradores da crise, o sujeito também passa a ser uma posição de sujeito dentro desse discurso que foi capaz de "domesticar" essa realidade que o excedia.

Dentre essas emergências do real, destaco no primeiro caso analisado, isto é, o caso de regulação do direito de greve de servidores públicos pelo Judiciário, a demora legislativa. O discurso de separação de poderes não entraria em xeque se dependesse apenas das previsões constitucionais. Acontece que a reiterada recusa do Legislativo em dar provimento ao gozo de um direito constitucionalmente garantido, gerou instabilidades num discurso jurídico em que, já sob o auspício de novas teorias políticas e jurídicas menos formalistas, figurava como um de seus elementos importantes a efetivação dos direitos constitucionalmente previstos. Essa mesma instabilidade se apresenta no segundo caso, ou seja, o caso do julgamento das pesquisas com células-tronco, em que o avanço da biomedicina fez com que o discurso tradicional de respeito à vida e à dignidade das pessoas dentro do Direito passasse a não dar conta dos avanços científicos sem distinguir, ou não, o status das pessoas já nascidas e o dos embriões. 
Já no terceiro caso, o caso da fidelidade partidária, dentro de um sistema partidário em que o normal seria o candidato se manter no partido que o elegeu, a recorrente infidelidade partidária também se tornou um elemento de instabilidade desse discurso que precisava se transformar e definir melhor certos pontos - se o mandado pertence ao partido ou ao candidato - que, em tese, não precisariam entrar em conflito, mas que, de fato, estavam entrando. Por fim, nos outros dois casos analisados, pode-se apontar dentre tais imprevistos da realidade, incapazes de se encaixar plenamente nas formações discursivas à disposição dos sujeitos, primeiro, no caso das demissões da EMBRAER, a crise econômica mundial e suas consequências tanto para a liberdade dos empregadores quanto para as garantias dos empregados, e, segundo, no caso das cotas raciais nas universidade, o incômodo da persistência de uma desigualdade racial que o discurso de igualdade focado na dimensão formal não era capaz de aliviar.

Uma das formas de assimilação discursiva do deslocamento, na obra de Laclau, é o antagonismo, em que uma posição diferencial passa a ser entendida como também um obstáculo a uma identidade à qual se contrapõe. Como já transparece no parágrafo anterior, essa assimilação enquanto antagonismo, base para a ação política, é o que aconteceu nos casos analisados. Quando a emergência do real é significada como algo além do controle da ação humana - derivada da vontade de Deus, da natureza, ou de um imperativo sistêmico, por exemplo - o espaço para a ação política e transformação dos discursos permanece fechada. Os servidores públicos poderiam entender que a não regulamentação do seu direito de greve derivava de uma demora normal dentro do sistema democrático e assim, poderiam se manter passivos. Da mesma forma, se os trabalhadores da EMBRAER entendessem suas demissões como um automatismo sistêmico derivado do funcionamento autônomo da economia, não haveria recurso ao Judiciário. Contudo, não foi o que se observou e tais deslocamentos foram todos assimilados como antagonismos, abrindo-se às vias de transformação política e efetivando verdadeiros sujeitos sociais capazes de empreender transformações nos discursos típicos que buscavam configurar a situação em que se encontravam.

Dentro dessa lógica, no primeiro caso, a demora dos legisladores foi entendida como uma displicência legislativa que se oporia à concretização de direitos garantidos constitucionalmente, bloqueando-a. No segundo, com a possibilidade da destruição de embriões humanos para a realização de certas pesquisas, o progresso científico 
T\&P Ernesto Laclau e Chantal Mouffe e a análise do direito: mobilizando conceitos laclaunianos para a compreensão do fenômeno da judicialização da política e das relações sociais no Brasil

também passou a ser significado como opositor à garantia do direito à vida, igualmente constitucionalizado e juridificado. No terceiro, a migração partidária dos candidatos após as eleições passou a ser compreendida como um tipo de ação pragmática individual que bloqueava a consolidação de um regime democrático partidário. E nos casos de controle de constitucionalidade difuso, as demissões patrocinadas pela EMBRAER passaram a ser significadas como um tipo de ingerência do empregador que se oporia à dignidade dos trabalhadores e a reserva de vagas feita pela UFSC como uma afronta à igual consideração e respeito por todos.

Abria-se assim, em todos os casos, um espaço para a ação política, no sentido de ação que visa buscar hegemonia dentro de uma determinada configuração discursiva. Pois havia em todos eles um antagonismo - isto é, uma identidade entendida como bloqueadora de alguma outra - e também uma representação da plenitude ausente que permitia que cada uma daquelas demandas particulares se apresentasse como universal, falando em nome da Constituição (primeiro caso), da vida (segundo caso), da democracia (terceiro caso), da dignidade humana (caso EMBRAER) e da igual consideração e respeito por todos (caso UFSC). Em nem todos os exemplos essa articulação discursiva e movimento sinedótico logrou êxito e a hegemonia foi obtida no sentido pretendido por aqueles que mobilizaram o aparelho Judiciário. Mas em todos eles é possível compreender que houve uma ação política que via no Judiciário uma arena privilegiada para se desenrolar em direção à busca de hegemonia.

Cabendo ao Judiciário a guarda da Constituição e estando constitucionalizados uma série de significantes de tendencial vacuidade, incluindo a Constituição em si, esse Poder se abre à luta pela hegemonia e, por vezes, se mostra como estrategicamente privilegiado para tanto. Um exemplo claro são os chamados "casos quentes" que impõem à arena Legislativa custos altos dentro de uma lógica dependente de votos, excluindo sistematicamente dessa arena determinadas demandas. É onde se encaixa o primeiro e, em certo sentido, também o terceiro casos estudados. Outro exemplo reside em situações que pretendem reverter a hegemonia obtida alhures, apelando a um princípio constitucional contra uma decisão política majoritária já tomada no Legislativo. O segundo e, mais uma vez, em certo sentido, o terceiro casos estudados podem ser entendidos como representantes dessa situação. E, por mais lentos que sejam as disputas judiciárias, a busca por uma liminar na justiça pode se apresentar como um caminho 
mais célere para a concretização de dada demanda do que tentativas de modificar a posição de certas instituições públicas ou privadas por meio de greves, passeatas, etc. É o que justifica o caminho judicial para as ações deflagradas pelos autores das ações dos casos EMBRAER e UFSC.

Assim, símbolos da uma plenitude ausente - como a igualdade, a liberdade, a dignidade, a ordem constitucional, etc. - politizam o Direito abrindo-o à necessidade de preencher com significados específicos esses significantes de tendencial vacuidade, da mesma forma que ocorre na disputa política parlamentar, nos movimentos sociais, na formação de identidades coletivas, etc. e, consequentemente, reprimindo as alternativas discursivas que não conseguiram a hegemonia. Isso tudo não impede, por certo, que, por mais que a teoria da hegemonia, tal como desenvolvida por Laclau e utilizada neste estudo, seja pensada num nível de abstração capaz de abarcar a ação política em todos esses modelos, existam diferenças de um modelo para o outro e existam especificidades nas práticas hegemônicas, por exemplo, dentro das instituições jurídicas e legislativas ou das instituições jurídicas e dos movimentos sociais.

\section{A lógica social e a lógica política nos tribunais brasileiros}

Compreendida nesses termos, a decisão judicial passa a ser uma espécie de decisão política, que visa reagir a um deslocamento identificado como um antagonismo social. Tomada em bases contingentes, essa decisão rearticula uma formação discursiva estabelecendo novas fronteiras e identidades coletivas que inovam o significado do próprio discurso, tornando o que era antes apenas um elo dessa cadeia discursiva a representação de sua universalidade e instituindo uma hegemonia capaz de produzir um estancamento precário no fluxo de sentidos possíveis dentro do campo de discursividade afetado pela decisão. Ou seja, a decisão judicial não é muito diferente de outros tipos de decisões que dão identidade a demandas de movimentos sociais ou partidos políticos. Essa lógica informa melhor a prática judicial do que compreensões mais técnicas, que presumem decisões a serem tomadas sobre bases incontestáveis.

Quando um médico aplica uma medicação ao paciente, atua na proteção desse paciente apenas, devendo unir a medicação e o organismo doente com o propósito de preservar a vida como um bem presumido valioso. Os pressupostos dessa atuação 
T\&P Ernesto Laclau e Chantal Mouffe e a análise do direito: mobilizando conceitos laclaunianos para a compreensão do fenômeno da judicialização da política e das relações sociais no Brasil

- por exemplo, de que a vida é um bem valioso em si mesmo e que o corpo humano pode ser medicado - não são questionados e o conflito a ser resolvido, entre paciente e doença, deve ser resolvido em favor do primeiro. Essa atuação técnica tende a se desenrolar sobre o que Laclau e Mouffe consideram o "social", isto é, práticas discursivas bastante sedimentadas, que não sofrem deslocamentos constantes.

Exercícios de imaginação podem sugerir possíveis situações de instabilidade nessas pressuposições do médico - isto é, para fazer uso do vocabulário de Laclau, situações em que a emergência de uma realidade que não consegue ser domesticada pelos discursos à disposição dos sujeitos, causa uma desarticulação estrutural que põe em disputa o significado do que antes era pressuposto. Parece claro que um organismo que parasite o corpo humano deve ser eliminado para permitir a continuidade da vida humana. Mas digamos que esse corpo humano venha a ser o de um clone, vítima de uma experiência buscando a cura de milhares de pessoas, ou que esse parasita, agora indo mais longe na ficção científica, seja um organismo alienígena de uma nação amiga de planeta outro. A desigualdade presumida entre o status e a dignidade do corpo humano e o status e dignidade de seu parasita poderia ser, nesses casos, questionada e a atuação do médico passaria a ser menos uma atuação técnica do que uma ação política visando redelimitar a identidade do que seria a humanidade ou as fronteiras entre amigos e inimigos de uma política externa interplanetária. Para não fazer necessários exercícios imaginativos tão delirantes, basta pensar na controvérsia dos casos de eutanásia, onde uma vida tida por indigna torna instável a pressuposição comum aos tratamentos médicos de que a vida humana é um bem em si mesmo.

Essas decisões de caráter mais político do que técnico não tendem a emergir com frequência na prática do médico que busca curar seus pacientes. No entanto, há razões para acreditar que essa emergência é muito mais comum na prática do juiz que visa solucionar os conflitos levados a um tribunal. Como destacam Martin Shapiro e Alec Stone Sweet, se o juiz não tivesse de escolher entre alternativas, se ele simplesmente aplicasse a regra fornecida a ele pelos estatutos e alcançasse sua conclusão comandado por uma lógica jurídica inexorável, ele não seria mais interessado politicamente do que uma máquina da IBM, que poderia ser projetada para substituí-lo. No entanto, reconhecendo-se que a escolha é inerente às fases do comportamento humano que têm sido tradicionalmente objeto dos estudos jurídicos, o adjetivo "política" passa a 
poder ser ligado à atividade judicial, que se torna assim, atividade política (SHAPIRO; SWEET, 2002, p. 20).

Existem casos judiciais que geram decisões como as do médico que deve curar a doença de um paciente. São casos em que o juiz pode pressupor um consenso bastante estável sobre quem deve ter razão na causa sob seu julgamento. Mas, em princípio, uma causa judicial envolve partes numa situação de igualdade, cada uma reclamando que o direito local está em seu socorro e não em socorro de seu concorrente. Uma defesa meramente protelatória, ou meramente de pedido de redução de uma punição aceita como merecida, ainda assim mobilizam um questionamento jurídico a respeito do direito possuído pela parte que acusa. As prescrições do Direito existem para serem obedecidas e, dessa forma, fazer parte do social, do garantido, do presumido como correto, do inconteste. Mas quando é desobedecido e gera uma demanda judicializada e depois resistida, o direito é fonte de um antagonismo e as decisões a seu respeito passam a ser políticas.

Um exemplo corriqueiro de uma situação jurídica de solução fácil, isto é, que apenas reproduziria os pressupostos estáveis do que Laclau e Mouffe chamam de social, é o da multa por ultrapassagem do limite de velocidade de uma via. Se está sinalizado que o limite de velocidade de determinada via é de $60 \mathrm{~km} / \mathrm{h}$, trafegar em tal via a, por exemplo, 80 km/h seria infração sujeita a multa. Mesmo assim, resta possível questionar a pertinência do limite de velocidade imputado àquela via levando em conta políticas mais gerais de organização do trânsito. Se outras tantas vias, na mesma situação daquela, permitem uma velocidade maior, uma pessoa multada por excesso de velocidade poderia questionar o porquê de justamente a via em que foi multada ter um limite de 60 km/h, mesmo estando na mesma situação - por exemplo, em linha reta, sem inserção em perímetro urbano ou cruzamentos, etc. - de outras que permitem o tráfego a 80 ou 110 km/h. Ela poderia cobrar uma justificativa para o tratamento diferenciado daquela via e, em não havendo tal justificativa, não seria impossível ao Judiciário decidir em seu favor entendendo que houve violação à igual consideração e respeito entre o motorista multado e os demais que trafegam a maiores velocidades em vias outras do mesmo tipo daquela.

Por conta disso, a decisão judicial, especialmente quando aceita sua formatação não apenas por regras, mas também por princípios, aproxima-se mais de decisões

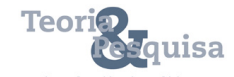


políticas, que visam domesticar o político enquanto ontologia conflituosa, do que de decisões técnicas que visam reproduzir discursos sedimentados como certezas. Voltando ao exemplo do médico, ele aplica o medicamento, que é assimilado pelo doente. O juiz não faz algo desse tipo com a lei. A lei não é aplicada e assimilada pelo caso concreto. Ela altera o entendimento a respeito daquele caso - por exemplo, o que era uma briga de vizinhos passa a ser uma causa judicial - e é por ele alterada gerando um precedente que influencia a sua interpretação futura. Mas a norma e o caso permanecem independentes um do outro, sendo apenas contingentemente articulados, como acontece numa demanda política, em que grupos diferentes falam em nome da igualdade, da liberdade, etc., permanecendo como unidades independentes umas das outras, de um lado, tais valores e, do outro, os movimentos sociais ou partidos políticos que os mobilizam.

Como num antagonismo social não estão decididos de antemão quem devem ser os vencedores e os vencidos - ao contrário do embate entre o paciente e sua doença - resta aos grupos disputarem quem fala em nome da universalidade. Sejam esses grupos partidos políticos, sejam partes num processo. Seja um partido socialdemocrata fazendo oposição a um partido liberal afirmando que o liberalismo não promove a igual consideração e respeito por todos, seja a pessoa do exemplo anterior, multada por excesso de velocidade usando a mesma igual consideração e respeito por todos para se defender de tratamento, a seu ver, injusto. Uma pretensão jurídica resistida num tribunal ou a oposição política no parlamento tendem a gerar decisões políticas no sentido proposto por Laclau e Mouffe, já que, de acordo com esses autores, a política é justamente a dimensão social de amortização do político, que representa uma ontologia baseada no conflito.

Nem toda decisão tomada na esfera política, tal como essa esfera é compreendida corriqueiramente - isto é, no interior da estrutura do Estado, ou na manifestação de partidos políticos e de movimentos sociais, etc. - é uma decisão política no sentido proposto por Laclau e Mouffe. Um político, no sentido profissional do termo, ou uma instituição política, como o Congresso Nacional, tomam no dia-a-dia, decisões mais técnicas, ou mesmo visando vantagens pessoais, como em transações econômicas. Um partido e um governo que busca formar uma coalizão podem negociar cargos, apelando somente às vantagens que a negociação traria a cada um dos lados, sem 
redelimitar identidades coletivas, apelar a valores universais ou confrontar projetos de uma sociedade melhor. Da mesma forma, há casos jurídicos em que a tendência de a decisão ser favorável a uma das partes é tão forte, que o tribunal se torna mais o palco de barganha econômica - por exemplo, negociação de uma dívida reconhecida pelo devedor - do que o conflito entre diferentes formas de entender o direito do país, cada qual dando razão a uma das partes.

No entanto, apesar de casos desse tipo, os tribunais e parlamentos são tendencialmente o palco de desenvolvimento de um conflito mediado por regras próprias, cuja decisão final sempre apresenta certa contingência. Se assim não fosse, os que disputam esse jogo político não aceitariam as suas regras. Logo, o potencial de formatação de antagonismos sociais no Direito é inato. Mesmo assim, tem-se a impressão de que apenas recentemente o Direito teria se tornado propriamente político. E, em certo sentido, isso é verdade, pois é nas democracias constitucionais contemporâneas que a dimensão política do Direito se radicaliza.

As democracias constitucionais são mais radicalmente políticas por serem mais radicalmente abertas à participação das mais variadas camadas da sociedade como intérpretes de suas normas e clientes de suas instituições. Para a promoção de tal abertura restam fundamentais tanto a "constitucionalização simbólica" criticada por Marcelo Neves (2007), quanto a presença no mundo jurídico dos "patéticos postulados éticos" da justiça e dignidade humana que Weber condenou como completamente inadequados a um Direito que tendia à formalização (WEBER, 2004, p. 146). A inserção desses símbolos de tendencial vacuidade no mundo do Direito é ao mesmo tempo tanto um fator gerador de instabilidade, quanto um fator de democratização, no sentido de abertura da jurisdição à sociedade. A garantia de que o Direito servirá a todos é o que não permite garantir seus resultados. Logo, a segurança jurídica só pode existir no sentido de segurança sobre a apreciação de uma demanda sob os auspícios do Direito e não no que diz respeito a seus resultados.

Neste contexto, a judicialização da política tem como seu corolário a politização da justiça. E, nos meandros dessa justiça politizada, como partidos ou movimentos sociais, as partes do processo representam seu lado, mas fazendo com que ele almeje a universalidade. Esse aspecto se radicaliza nas demandas coletivas e de controle do

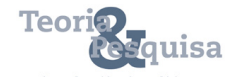


T\&P Ernesto Laclau e Chantal Mouffe e a análise do direito: mobilizando conceitos laclaunianos para a compreensão do fenômeno da judicialização da política e das relações sociais no Brasil

processo legislativo, onde o caráter dessas demandas, de serem expressão de um grupo que tenta falar em nome da coletividade, torna-se ainda mais explícito.

\section{Conclusão: radicalização da democracia nos tribunais brasileiros?}

Diferenciando analiticamente as causas da judicialização das relações sociais das causas da judicialização da política, Gisele Araújo destaca que a judicialização das relações sociais é uma juridificação da vida social patrocinada pelo poder Executivo, por meio de uma regulamentação estatal da sociedade que se amplifica e incha o Judiciário com demandas de particulares e de grupos sociais por prestações estatais positivas. Seu circuito seria assim, originado formalmente no Estado, passando pelo Direito e tendo como destino a regulação da Sociedade. A judicialização da política, por seu turno, ela complementa, seria fenômeno diverso, que realizaria, potencialmente, um percurso invertido. Nesse caso, a cadeia de transmissão se iniciaria na sociedade, incluindo suas instituições de representação, que acionaria o sistema jurídico para obter resultados políticos (ARAÚJO, 2011, p. 29).

Por conta disso, apesar de alguns autores vincularem a judicialização da política também às transformações do Direito causadas pelo Estado de Bem-estar Social, a autora entende como sendo mais fecundo tomá-la como um "[...] efeito a médio prazo das mudanças advindas do Constitucionalismo democrático europeu do pós-Segunda Guerra, que se fará presente nas Constituições de Portugal, Espanha e de alguns países latino-americanos nas décadas de 1970 e 1980". Araújo (2011, p. 30-31) reconhece que "[...] muitos dos direitos antiliberais típicos do Welfare State foram transformados em dispositivos constitucionais". No entanto, ela continua, "[...] até meados do século XX, as Constituições eram cartas de princípios ou de intenções de reduzida eficácia". A exigibilidade dos direitos constitucionais, ela completa, só começaria a se verificar quando é conferido "[...] caráter prático à supremacia da Constituição [...] e quando se desenvolvem institutos processuais para viabilizar seu cumprimento, a serem acionados por atores sociais". Por isso, ela conclui, o atual papel de destaque do Poder Judiciário se reforça a despeito da mitigação do Estado de Bem-estar Social observada nas últimas décadas do século XX, tendo "[...] como lastro principal a afirmação da Constituição 
como conjunto de dispositivos a serem observados por toda a sociedade, aí incluídos o Executivo e o Legislativo" (ARAÚJO, 2011, p. 30-31).

Tendo isso em vista, para a autora, na contramão das formulações de GuntherTeubner, a principal questão envolvida na judicialização da política não seria a da maior ou menor eficácia do Direito, envolvendo, por conseguinte, um "trilema regulatório". Segundo ela, em analogia ao que Teubner diagnosticou para o Direito sob o Estado-Providência, poder-se-ia dizer que,

[...] sob a judicialização da política, vive-se uma espécie de "trilema democrático", composto por alternativas contraditórias entre si: o avanço do Poder Judiciário no controle e instituição de normas ou (a) ameaça terminantemente a representação legislativa e a legítima produção do Direito, instituindo a arbitrariedade ademocrática de um corpo pseudoaristocrático; ou (b) pode ser contido pelo rebustecimento do Legislativo, afirmando-se este como representante único das demandas sociais, reconhecido como tal e eficaz nesta sua função; ou (c) pode significar a abertura de um novo canal de comunicação entre sociedade e Estado, permitindo que o Legislativo e o Judiciário - além do Executivo, notadamente em países presidencialistas - sejam destinatários, de formas distintas e talvez complementares, da vontade popular (ARAÚJO, 2011, p. 32).

A autora destaca então que nenhuma dessas três hipóteses é, ao menos no campo da teoria, inviável. E, com base nisso, passa a argumentar a favor da pertinência da terceira dessas possibilidades, concluindo que:

Na medida em que ao Judiciário é conferido o poder de interpretar o Direito ao ponto de contê-lo, reformá-lo ou proclamá-lo, cumpre verificar se isto significa por definição um assalto à democracia, ou se tem o potencial, a ser reconhecido empiricamente, caso a caso, de ser um movimento que multiplica as formas de acesso à esfera pública. Se isso for teoricamente possível, então os diagnósticos que vêem a atual "crise de separação dos poderes" imediatamente como uma "crise da democracia" são, pelo menos, incompletos. Supõe-se adiante um outro cenário: o de que a judicialização da política pode ser um movimento de deságue de pretensões sociais que não encontram expressão nas outras esferas estatais e que podem, evidentemente, ser acolhidas ou não a depender da estrutura, composição e cultura dos Judiciários realmente existentes ( ARAÚJO, 2001, p. 33).

Para configurar esse outro cenário, Araújo faz uso da noção de soberania complexa de Pierre Rosanvallon. Trata-se de noção de soberania que, contra o monismo político - que 
T\&P Ernesto Laclau e Chantal Mouffe e a análise do direito: mobilizando conceitos laclaunianos para a compreensão do fenômeno da judicialização da política e das relações sociais no Brasil

só reconhece no Legislativo e nas eleições que o sustentam os canais de representação democrática - compreende que devem fazer parte da política outras formas de representação, como a representação funcional, exercida pelos que falam em nome do povo de acordo com o que é organizado e reconhecido nos textos que organizam a vida pública: as leis e sobretudo a Constituição (ROSANVALLON, 2000, p. 431). É com base nessa noção de soberania complexa que a autora coloca em destaque que "[...] permanece contemporâneo o desafio de encontrar arranjos sócio-institucionais que admitam a diversidade social canalizada através de formas plurais de representação que sejam legítimas e igualitárias". Para então concluir que:"[...] a ida da sociedade e de suas associações ao Judiciário - além do Legislativo e do Executivo - talvez possa ser entendida como um movimento, ainda que incipiente, multifacetado e não sem riscos, nessa direção" (ARAÚJO, 2011, p. 40).

Com base na compreensão de política e de sociedade desenvolvidas por Laclau e Mouffe, o presente trabalho compartilha com Gisele Araújo (2011) e Pierre Rosanvallon (2000) a compreensão de que a diversidade social contemporânea demanda formas plurais de representação e que, em princípio, não há nada que impeça o Judiciário de se apresentar como um desses canais de expressão da vontade popular. As formas como essas possibilidades de uso democrático do Poder Judiciário se expandem, ou contraem, precisam ser avaliadas caso a caso, sob uma perspectiva teórica que permita sua avaliação empírica.

A percepção de inspiração luhmaniana de que "[...] o sistema jurídico é dotado de uma unidade organizacional e operativa - coisa julgada, princípio da inércia, 'non liquet' - que o torna uma estrutura inábil para trabalhar com temáticas politizadas" (GONÇALVES, 2011, p. 89) não precisa ser revertida e cristalizada num postulado teórico que só permita entender a politização da justiça como um indevido momento de alopoiese em que sistemas que precisavam ser independentes - o sistema político, o sistema jurídico, o sistema econômico, etc. - graças à diluição de suas fronteiras de atuação, destroem o projeto de diferenciação funcional da modernidade. Sob uma perspectiva em que não apenas sistemas regulam a vida das pessoas, mas também em que as pessoas são capazes de rearticular o fundamento dos seus sistemas, se as instituições jurídicas não têm sido hábeis para processar demandas politizadas, disso não decorre, necessariamente, que essas demandas politizadas precisam ser excluídas 
da apreciação judicial. Nada impede que, pelo contrário, sejam as instituições jurídicas as modificadas para que melhor respondam a essas demandas.

O que seria, nessa perspectiva sistêmica, o sistema político em sentido estrito, também possui suas limitações no processamento de demandas políticas no sentido mais amplo do termo. Não há como negar a importância das eleições para a constituição de uma verdadeira democracia representativa. Mas a dependência do voto por parte dos membros dos poderes Executivo e Legislativo não deixa de ser um obstáculo à recepção de determinadas demandas sociais, sobretudo de grupos numericamente minoritários, como é o caso das minorias sexuais e religiosas. A temporalidade de poucos anos com que trabalham os políticos que têm objetivos eleitorais de curto prazo, também pode ser empecilho à recepção de demandas que cristalizam seus efeitos no longo prazo, como por exemplo, as demandas por preservação ecológica. Numa perspectiva estreita de soberania e de política, demandas como essas correm o risco de serem sistematicamente excluídas de apreciação pelos representantes do povo. A não ser que outros tipos de representação sejam pensados, como a representação funcional destacada por Rosanvallon (2000).

Dada a sua independência com relação ao sistema eleitoral, os juízes podem aparecer como agentes políticos capazes de dar guarida a demandas desse tipo, como representantes de princípios comunitariamente compartilhados, fazendo uso da igual consideração e respeito por todos para fundamentar direitos de minorias sexuais, da laicidade do Estado para proteger minorias religiosas, ou do princípio responsabilidade de Hans Jonas (2006) para fomentar a proteção ambiental. Se, conforme admitido anteriormente, esse caminho de expansão da representação comporta riscos, nem por isso ele deve ser desprezado simplesmente por fidelidade a um modelo conceitual, dependente de uma sociologia do Direito que reduz a atividade judicial, necessariamente, à leitura da realidade por meio do binômio lícito/ilícito. Se a situação específica do Judiciário, que - ao contrário do que acontece com o Legislativo e Executivo - extrai sua legitimidade de sua independência, coloca sua abertura sob a tensão da instrumentalização, nem por isso um ideal de direito socialmente mais responsivo precisa ser abandonado de pronto em favor de um retorno a um direito socialmente insulado como único sistema portador do significado de o que seria o verdadeiro Direito. 
T\&P Ernesto Laclau e Chantal Mouffe e a análise do direito: mobilizando conceitos laclaunianos para a compreensão do fenômeno da judicialização da política e das relações sociais no Brasil

Conforme os casos estudados, os juízes insistem na diferenciação das suas funções perante funções legislativas e morais, por exemplo. Mas não se fecham num sistema autônomo e auto-suficiente e tampouco baseiam suas decisões apenas no contraponto entre lícito e ilícito. Se os casos também mostram tensões e dificuldades na relação entre os juízes e as novas demandas que lhes são apresentadas, isso não é motivo para excluir tais demandas do Judiciário, já que algumas delas lá chegaram por não encontrar espaço no Legislativo. Se, por um lado, é necessário que se tome cuidado e se pense alternativas perante os riscos trazidos à democracia pela delegação de poder a um corpo de representantes não eleitos, essas alternativas não precisam ser o bloqueio desse canal de expressão de demandas populares que, ao menos em princípio, possui potencial democrático, na forma em que a democracia e o Direito têm sido aqui compreendidos.

É por isso que insisto numa representação das instituições jurídicas que possa ser entendida como uma formação discursiva que carrega em si possibilidades múltiplas, dentre elas a de um direito radicalmente democrático. Sob esse ponto de vista, o projeto de Chantal Mouffe de uma democracia radical, que requer a democratização da multiplicidade de dimensões da sociedade, poderia encontrar suporte na forma como Rosanvallon (2000) desafia o monismo político, clamando por uma expansão generalizada dos procedimentos democráticos e dos canais de representação democrática, incluindo, em tal expansão, instituições jurídicas. Tal possibilidade seria aberta pelo que Nonet e Selznick (2005), em sua classificação dos sistemas jurídicos entre os tipos repressivo, autônomo e responsivo, irão chamar de um sistema jurídico responsivo. Isto é, um sistema jurídico cujas principal característica passaria a ser não a mera imposição da força - característica de sistemas jurídicos repressivos - nem a instituição de um sistema de regras aplicado de maneira formal e neutra a todos - como num sistema jurídico autônomo - mas sim sua abertura às demandas sociais por justiça substantiva - tal como os autores observavam nos movimentos por direitos civis que emergiam nos Estados Unidos a partir da década de 60.

As reflexões teóricas do presente trabalho caminham, portanto, no sentido de reconhecer o potencial democrático das instituições de um Judiciário, nos termos de Nonet e Selznick (2005), socialmente responsivo, pois este ampliaria os canais de expressão hegemônica. Claude Lefort, cuja noção de democracia embasa fortemente as concepções sociais e políticas de Laclau e Mouffe, destaca que a uma das principais características 
da democracia é o"vazio" gerado nas instituições de governo (LEFORT, 1986, p. 28). Essa característica da democracia permite que qualquer grupo possa se tornar o porta-voz da coletividade - diferentemente, por exemplo, de um governo dinástico em que poder político e consanguinidade andam juntos. Se o Judiciário responsivo, pela abertura de suas instituições e do entendimento acerca de seus institutos, também é marcado pela explicitação do esvaziamento dos marcos de certeza que antes garantiam sistemas jurídicos mais fortemente repressivos e socialmente autônomos, pode-se dizer que ao mesmo tempo em que ele ganha instabilidade, ganha também potencial democrático.

Os casos estudados confirmam, na prática, esse esvaziamento e flexibilização dos institutos do direito brasileiro. Trata-se de exemplos em que diferentes grupos - trabalhadores organizados, partidos, segmentos religiosos, estudantes, etc. - por diferentes meios mandado de injunção, ação direta de inconstitucionalidade, recursos processuais, etc. transformaram antagonismos sociais em disputas judiciais apresentando suas demandas particulares como portadoras do real significado dos valores universais expressos na Constituição. Contudo, como são representantes de apenas alguns casos emblemáticos, mas pontuais, da judicialização da política e das relações sociais no Brasil, esses dados servem apenas para confirmar o potencial democrático de um Direito responsivo e não para validar a consolidação desse modelo jurídico no Brasil. Para isso, restariam necessários estudos mais sistemáticos, capazes de avaliar as duas dimensões capazes de mostrar o quão responsiva é determinada ordem jurídica: a dimensão da pluralidade de demandas que recebe e a dimensão das respostas que dá a essas demandas.

\section{Referências}

ARAÚJO, G. S. Judicialização da política: as possibilidades da democracia para além do monismo político e identitário. In: MOTTA, L. E.; MOTA, M. (Orgs.). O Estado Democrático de Direito em questão: teorias críticas da judicialização da política. Rio de Janeiro: Elsevier, 2011.

ASENSI, F. D. Juridicização das relações sociais e Ministério Público: novas estratégias e desafios na efetivação do direito à saúde. 2008. Dissertação (Mestrado)-Instituto Universitário de Pesquisas do Rio de Janeiro, Universidade Cândido Mendes, Rio de Janeiro, 2008.

BADINTER, R.; BREYER, S. (Orgs.). Judges in contemporary democracy. New York: New York University Press, 2004.

DWORKIN, R. O Império do Direito. São Paulo: Martins Fontes, 2003 [1986].

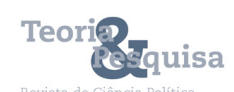


T\&P Ernesto Laclau e Chantal Mouffe e a análise do direito: mobilizando conceitos laclaunianos para a compreensão do fenômeno da judicialização da política e das relações sociais no Brasil

DWORKIN, R. Uma questão de princípio. 2. ed. São Paulo: Martins Fontes, 2005 [1985].

DWORKIN, R. Justice for hedgehogs. Cambridge: Belknap Press of Harvard University, 2011.

GONÇALVES, G. L. Entre politização e judicialização: limites estruturais do direito e da política. In: MOTTA, L. E.; MOTA, M. (Orgs.). O Estado Democrático de Direito em questão: teorias críticas da judicialização da política. Rio de Janeiro: Elsevier, 2011.

HIRSCHL, R. The judicialization of politics. In: WHITTINGTON, K. E.; KELEMEN, R. D.; CALDERA, G.

A. (Eds.). Oxford handbook of law and politics. Oxford: Oxford University Press, 2008.

JONAS, H. O Princípio responsabilidade: ensaio de uma ética para a civilização tecnológica. Rio de Janeiro: Contraponto, 2006 [1979].

KOERNER, A. K.; INATOMI, C. C.; BARATTO, M. Sobre o Judiciário e a judicialização. In: MOTTA, L. E.; MOTA, M. (Orgs.). O Estado Democrático de Direito em Questão: teorias críticas da judicialização da política. Rio de Janeiro: Elsevier, 2011.

LACLAU, E. Nuevas reflexiones sobre la revolucion de nuestro tiempo. 2. ed. Buenos Aires: Ediciones Nueva Visión, 2000 [1990].

LACLAU, E. Emancipation(s). Londres: Verso, 1996.

LACLAU, E. Construyendo la universalidad. In: BUTLER, J.; LACLAU, E.; ŽlŽEK, S. Contingencia, hegemonia, universalidad: diálogos contemporáneos en la izquierda. Buenos Aires: Fondo de Cultura Económica de Argentina, 2004 [2000].

LACLAU, E. La razón populista. Buenos Aires: Fondo de Cultura Económica, 2007 [2005].

LACLAU, E.; MOUFFE, C. Hegemonía y estrategia socialista: hacia una radicalización de la democracia. 2. ed. Buenos Aires: Fondo de Cultura Económica de Argentina, 2006 [1985].

LEFORT, C. La question de la démocracie. In: LEFORT, C. Essais sur le politique. XIXe e XXe siècles. Paris: Éditions du Seuil, 1986.

LOSEKANN, C. Mobilização do direito como repertório de ação coletiva e crítica institucional no campo ambiental brasileiro. Dados, v. 56, n. 2, p. 311-349, abr-jun. 2013.

MACHADO, I. S. Jurisdição, hegemonia e integridade: uma visão pós-estruturalista sobre o direito e sua relação com a sociedade e a política no Brasil. Dados, vol. 56, n. 4, p. 943-974, out-dez. 2013.

MACIEL, D. A. Ação coletiva, mobilização do direito e instituições polítias: o caso da Campanha da Lei Maria da Penha. Revista Brasileira de Ciências Sociais, v. 26, n. 77, p. 97-111, 2011.

MACIEL, D. A.; KOERNER, A. Sentidos da judicialização da política: duas análises. Lua Nova, n. 57, p. 113-134, 2002.

MCCANN, M. Litigation and legal mobilization. In:WHITTINGTON, K. E.; KELEMEN, R. D.; CALDERA, G. A. (Eds.). Oxford handbook of law and politics. Oxford: Oxford University Press, 2008.

NEVES, M. A constitucionalização simbólica. 2nd ed. São Paulo: Martins Fontes, 2007 [1994].

NONET, P.; SELZNICK, P. Law and society in transition: toward responsive law. 2nd ed. London: Transaction Publishers, 2005 [1978]. 
POGREBINSCHI, T. Judicialização ou representação? Política, direito e democracia no Brasil. Rio de Janeiro: Elsevier, 2012.

ROSANVALLON, P. La démocracie inachevée: histoire de la souveraineté du peuple em France. Paris: Éditions Gallimard, 2000.

SHAPIRO, M.; SWEET, A. S. On law, politics and judicialization. Oxford: Oxford University Press, 2002

TATE, C. N.; VALINDER, T. (Orgs.). The global expansion of the judicial power. New York: New York University Press, 1995.

TORFING, J. New theories of discourse: Laclau, Mouffe and Žižek. Oxford: Blackwell Publishers, 1999.

VIANNA, L. W. et al. A judicialização da política e das relações sociais no Brasil. Rio de Janeiro: Revan, 1999.

VIANNA, L. W.; BURGOS, M. Revolução processual do direito e democracia progressiva. In:VIANNA, L. W. (Org.). A democracia e os três poderes no Brasil. Belo Horizonte: Editora UFMG, 2003.

WEBER, M. Sociologia do direito. In:WEBER, M. Economia e sociedade. Brasília: Unb, 2004 [1921]. v. 2.

Recebido: 23 ago., 2016

Aceito: 05 nov., 2016 